\title{
FEATURE Stimulating soil health within Nebraska's Natural Resources Districts
}

Morgan Wirth-Murray and Andrea Basche

mproving soil health is increasingly recognized by farmers, researchers, policymakers, and agribusiness as a solution to a number of challenges facing agriculture, including rising soil degradation, growing climate change risks, and declining water quality (FAO 2011; Webb et al. 2017; Zimnicki et al. 2020). As a result of this additional focus on soil health, a number of new policy initiatives are being developed to support increased funding and capacity for soil health-related practices. This includes federal policies, through mechanisms such as the farm bill, which designate funding for national conservation programs to address natural resource concerns, of which soil health is one of many (Harrigan and Charney 2019). At present, these programs represent greater than US\$6 billion spent annually and are organized into various initiatives such as working lands programs, land retirement, easements, partnerships, and grants (CRS 2019). These dollars are distributed at the state level based on local resource needs and other technical considerations, through the USDA Natural Resources Conservation Service (NRCS) and/or their partner organizations (USDA ERS 2019; USDA NRCS 2020). In addition to federal support for soil health, there are a growing number of statewide initiatives; for example, the Nebraska legislature recently passed a bill to support the creation of a "Healthy Soils Task Force," a group of agricultural leaders in the state who are developing a roadmap for future soil health-related work in the state (NDA 2019). It is important to more closely consider the implementation of soil healthrelated programs, particularly at a local level, given increasing interest and investments.

NEBRASKA: A LEADING AGRICULTURAL STATE WITH UNIQUE LOCAL CONSERVATION GOVERNANCE

Nebraska is the fourth ranking US state for total agricultural commodities sold, which is considerable relative to the state's population of approximately 1.9 million (USDA ERS 2020; US Census Bureau 2020). More than $85 \%$ of the state's land area is either in cropland, dominated by the top field crops grown in the United Statescorn (Zea mays L.), soybean (Glycine max [L.] Merr.), and wheat (Triticum aestivum L.) — as well as grass or pasturelands utilized primarily for cattle production (USDA NASS 2020a). Nebraska also has the largest number of irrigated cropland acres in the United States (USDA NASS $2020 \mathrm{~b})$. Thus, it is a state at the interface of major agricultural commodity regions: the western Corn Belt; the wheat-producing states to the west, north, and south; and other major cattle producing states in the Great Plains. It is further unique in its governance structure to support natural resource conservation. In 1972, Nebraska developed the Natural Resources Districts (NRDs), local government entities whose goal is to protect natural resources. This came after condensing 154 single-purpose districts whose regulation authority was limited and scattered around diverse initiatives (Sixt et al. 2019). There are 23 NRDs in Nebraska whose geographic boundaries are based on river basin boundaries. This is novel among other states, which typically assign resource conservation based on county or other political borders. The NRD system is analogous to conservation districts in other states but unique in their boundary of focus. Aligning NRD boundaries with watershed divides allows the management of water and soil resources in logical hydrological units. Each local entity is composed of a board of directors, who are officials elected to four year terms, and staff members with expertise in water, soil, and other conservation topics. The local approach in Nebraska fits more with a bottom-up governance, which is seen to be appealing to a broad range of producers and stakeholders (Sixt et al. 2019). NRDs are able to formulate their own local approach to a set of standards

Received May 12, 2020. as they see fit to benefit their constituents while meeting state and federal government requirements. Furthermore, they are granted power to fund district operations and goals. The staff monitor progress toward these goals through measuring natural resources by a combination of physical, chemical, and social criteria, paying special attention to contaminants from both nonpoint source and point source pollution (NRD 2020).

Since their inception, many NRDs in Nebraska have focused efforts around managing groundwater quality and quantity. For example, the Upper Republican $\mathrm{NRD}$, in the southwestern region of the state, estimates that their regulatory efforts over the last several decades have resulted in $50 \%$ to $80 \%$ additional available groundwater quantity than what would have otherwise been available without restrictions (Upper Republican NRD 2020). Central Platte NRD is a good example of an area under groundwater quality monitoring given high concentrations of nitrate $\left(\mathrm{NO}_{3}^{-}\right)$in groundwater testing. Since 1987, Central Platte NRD has enacted a number of programs, including regulations such as limiting fertilizer application timing and techniques, as well as cost share, monitoring, and educational initiatives to support farmers. These programs have resulted in a steady decline of $\mathrm{NO}_{3}^{-}$levels over the last few decades (Central Platte NRD 2020). Although historically soil health has not been a focal area for the NRDs, there are a number of NRDs working to develop related programs given the increasing attention around the topic. In the last few years, the Upper Big Blue NRD, also a watershed with high levels of $\mathrm{NO}_{3}^{-}$in the groundwater, enacted programs to demonstrate

Morgan Wirth-Murray is a former undergraduate student in the School of Natural Resources, University of Nebraska-Lincoln, Lincoln, Nebraska. Andrea Basche is an assistant professor in the Department of Agronomy and Horticulture, University of Nebraska-Lincoln, Lincoln, Nebraska. 
on a larger scale the benefits of improving soil health to reduce water pollution (Upper Big Blue NRD 2020a). Further, Upper Big Blue and Central Platte NRDs have recently been awarded a large federal grant to pilot an ecosystem services market related to soil health (Upper Big Blue NRD 2020b).

\section{SOIL HEALTH-RELATED PERCEPTIONS AND PROGRAMS AT NEBRASKA'S NATURAL RESOURCES DISTRICTS}

Given the unique ability of the NRDs in Nebraska to enact watershed-scale programs and policies, and increasing attention paid to the topic of soil health, we recently administered an exploratory survey to understand perceptions, barriers, and ongoing initiatives amongst Nebraska NRD staff and board members. In addition, to develop the survey, we compiled information from publicly available budgets for the most recent fiscal year (2018) from each NRD to preliminarily evaluate different reported budget categories and amounts of spending.

In order to obtain a representative distribution of respondents who would be knowledgeable about NRD operations, we sought to send the survey to all board members and staff of each NRD in Nebraska. Due to a lack of publicly available emails and some privacy concerns, we were unable to obtain all contact information for every single staff person and board member at the NRDs; therefore, not all possible respondents received an individual email inviting them to participate in the survey. In total, we estimate that approximately 700 people had access to the online survey, and we received a total of 118 completed responses (with 115 providing demographic information, table 1). Natural Resource Districts with the largest numbers of completed surveys were located in the eastern and central regions of the state, including Central Platte (14), Lower Platte South (15), Lower Platte North (15), and Upper Big Blue (21), while there were a few NRDs with no responses (figure 1). As a result, we consider our results preliminary from the standpoint of robustness of responses across the NRDs.

\section{Table 1}

Demographic information for survey respondents. "Other" responses for position description included education, public relations, geographic information system (GIS), or secretary.

\begin{tabular}{ll}
\hline Characteristic & Number of responses \\
\hline Length of time associated with Natural Resource District & 18 \\
Less than 2 years & 30 \\
2 years to 5 years & 32 \\
5 years to 15 years & 35 \\
15 years or more & \\
Position description & 44 \\
Board member & 23 \\
Management & 11 \\
Staff: office/administrative support & 18 \\
Staff: water work & 9 \\
Staff: soil or conservation work & 10 \\
Other &
\end{tabular}

\section{Figure 1}

Map of Nebraska's Natural Resource Districts based on the number of responses received from respective locations. This included the following number of responses: Central Platte (14), Lewis and Clark (1), Little Blue (0), Lower Big Blue (3), Lower Elkhorn (5), Lower Loup (1), Lower Niobrara (6), Lower Platte North (15), Lower Platte South (15), Lower Republican (1), Middle Niobrara (3), Middle Republican (1), Nemaha (4), North Platte (7), Papio Missouri (4), South Platte (2), Tri-Basin (0), Twin Platte (1), Upper Big Blue (21), Upper Elkhorn (2), Upper Loup (3), Upper Niobrara White (5), and Upper Republican (1).

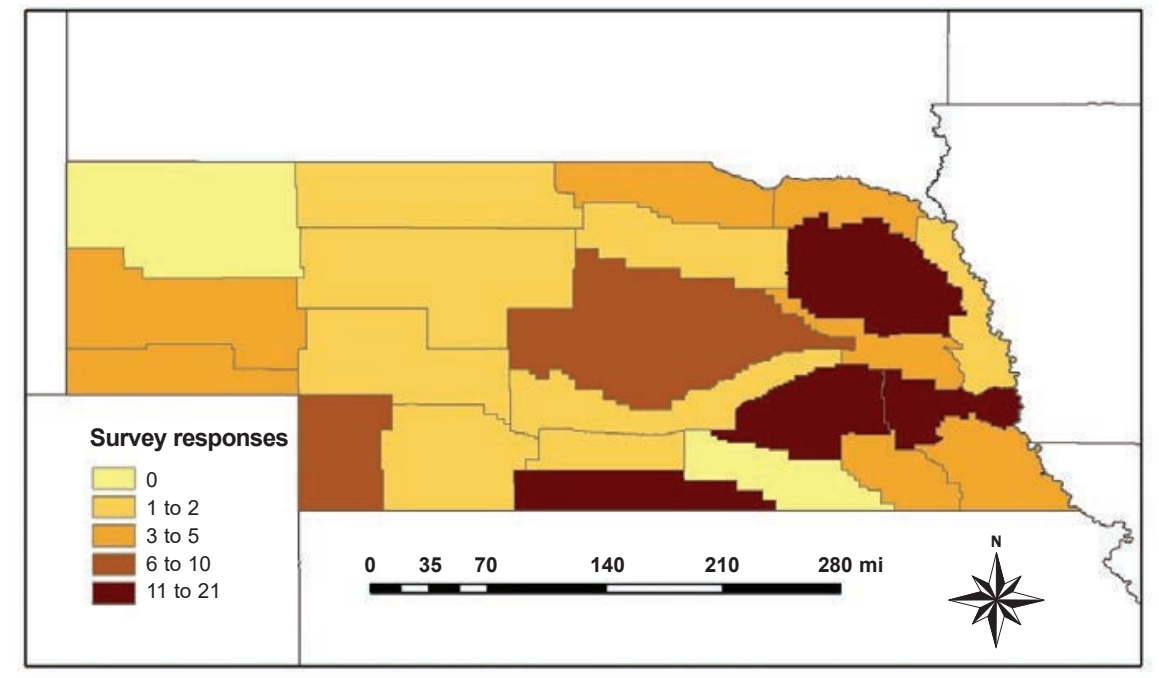

\section{PERCEPTIONS OF SOIL HEALTH AND IMPACTS OF CONSERVATION PRACTICES}

Most of the respondents showed favorable opinions pertaining to opportunities for improved soil health to address management and sustainability challenges (figure 2). There was near unanimous agreement in response to prompts such as "improving soil health/soil quality can address sustainability issues" and "it is important to make management decisions based on soil health/soil quality." Additionally, almost all respondents agreed that improving soil health could improve water quality and reduce soil erosion, and that "soil is a depletable resource." Further, there was large disagreement from respondents about a lack of importance toward using soil tests in their work, as most disagreed with the 
statements "I do not need to measure/test soil health/soil quality" and "I do not feel soil health/soil quality concepts help me in my professional work." In general we found that there was near unanimity in responses suggesting favorable perceptions of soil health. In response to the question "How much of an impact do you believe each of the following practices/items have on soil health/quality?", between $60 \%$ to $80 \%$ of respondents indicated that cover crops, diverse crop rotations, no till, and organic management could have a "large impact" (figure 3).

\section{STRUCTURE AND SUPPORT OFFERED WITHIN THE NATURAL RESOURCES DISTRICTS}

As a local governance system, the NRDs' primary source of financing is tax revenues. A maximum levy is set to US\$0.045 per US $\$ 100$, and each NRD has the capability of taxing up to that amount, but most do not (Little Blue NRD 2019). To change the amount taxed, a vote must be held by the board of directors. The amount each NRD receives is based on their upcoming projects as each NRD sets their own budget based on their local resource needs or employees, for example. In our preliminary analysis of the NRDs' budgets from 2018, we found that the amount of financial resources available ranged from US\$1.6 million to US\$72.2 million, with an average available resources to be estimated at US\$11.4 million (NAPA 2019). Respondents' open-ended answers to the question "To the best of your knowledge, what percent of your NRDs budget is dedicated to soil health programs?" ranged from $2 \%$ to as high as $90 \%$. The explanation of programs provided in the survey was that they "could represent educational incentives, cost share opportunities, or others," as our goal was to try to encompass any program whose efforts are dedicated to soil health.

Another open-ended question asked for examples of the soil health programs within the NRD. The most common answer was cost share programs, including no-till (11 responses), buffer strips (15 responses), and cover crops (20 responses). Specific initiatives such as Project SENSE (Sensors for Efficient Nitrogen Use and Stewardship of

\section{Figure 2}

Responses to the question "The following statements are related to soil health/ soil quality as concepts. How much do you agree or disagree with each of the following statements?"

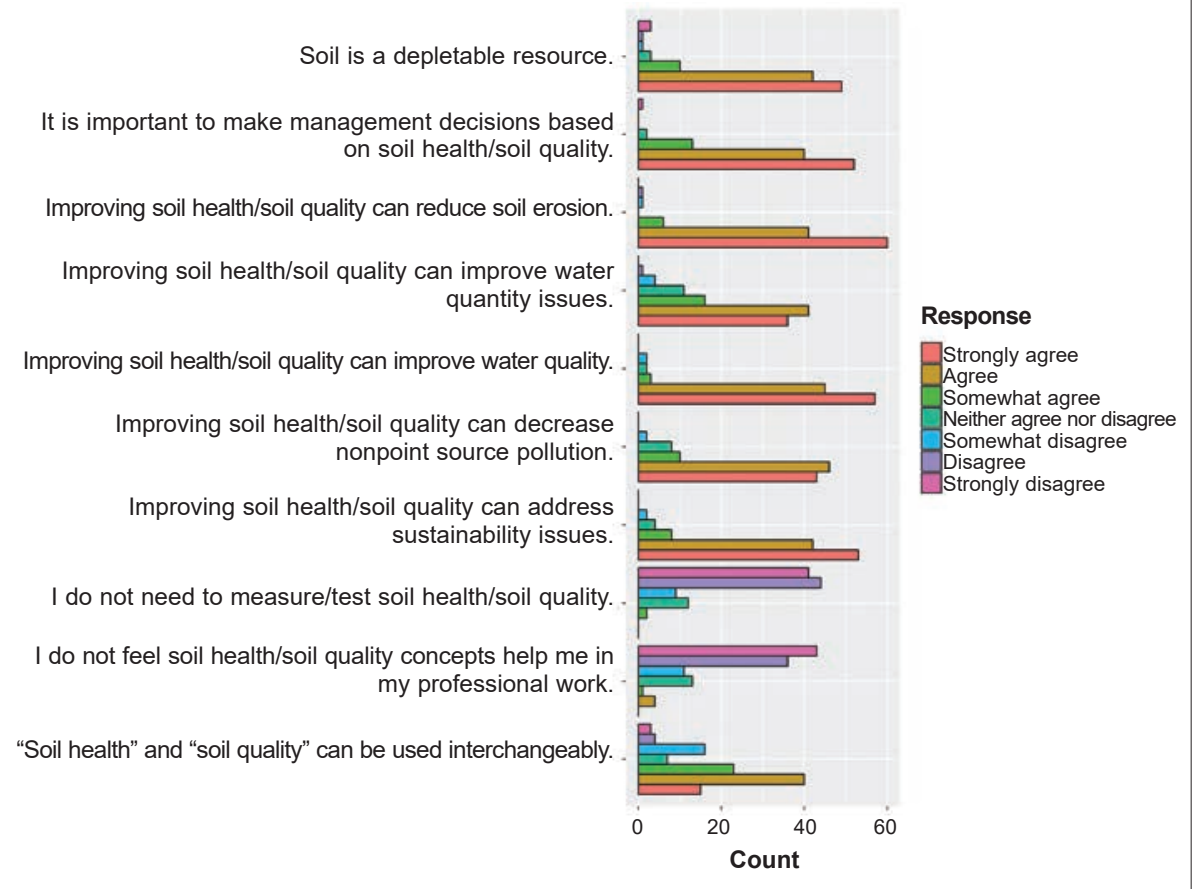

\section{Figure 3}

Responses to the question "How much of an impact do you believe each of the following practices/items have on soil health/quality?"

Wildlife habitat enhancement

Riparian buffers

Organic management

No-till

Livestock integrated on croplands

Grazing management (rotational, reduced stocking rates, etc.)

Diverse crop rotation (beyond corn/soybean)
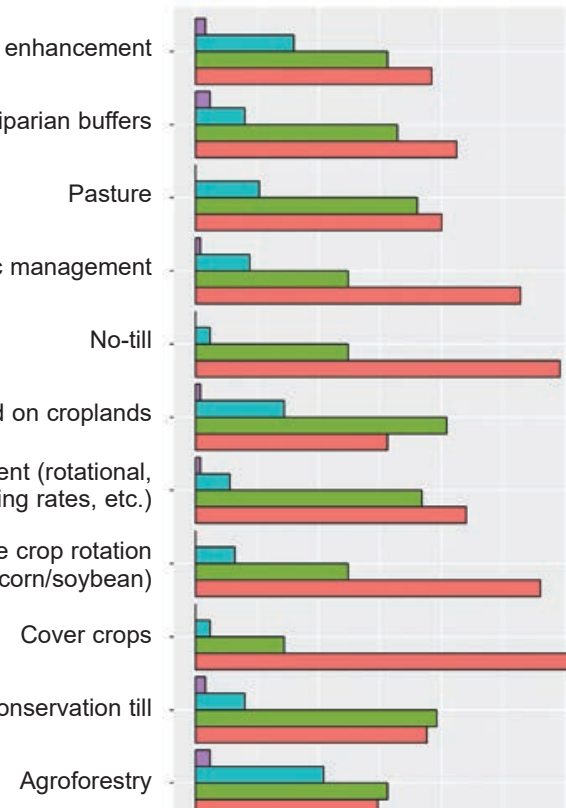

\section{Response}

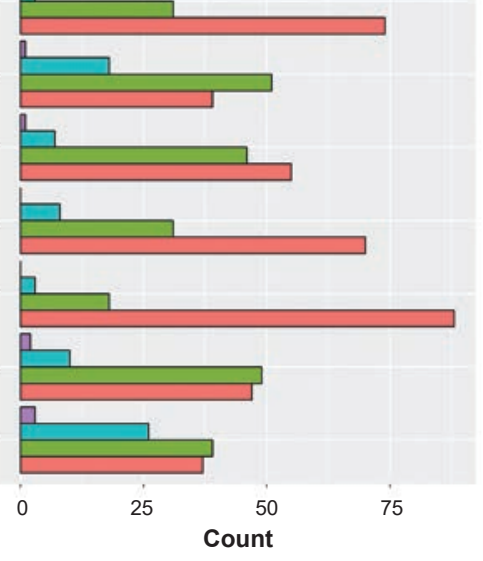


the Environment) and Nebraska Soil and Water Conservation Programs were mentioned a few times. Other broader programs mentioned were the Conservation Reserve Program, Conservation Tree Program, flood control, and soil testing. Education programs were listed as well, specifically education demonstrations by Central Platte NRD, the Project GROW (Growing Rotational crops On Wellfield) demonstration at Upper Big Blue NRD, and general youth education.

\section{"BEEN AT THIS FOR YEARS WITH LITTLE HEADWAY"}

In response to the question "How much impact do you believe each of the following initiatives would have on soil health in your NRD?", the majority of respondents felt that the largest impact on soil health would be a result of "more interest from farmers" (figure 4). Other initiatives seen as having potential to impact soil health included education with farmers, landowners, agribusiness, and other stakeholders, as well as more support for soil health testing. Surprisingly, respondents did not see increased funding as having the largest potential to impact soil health. Many left comments mentioning that communication and education with producers would aid in their mission and that investing in relationships with producers would have immeasurable benefits. Few responses reflected that an increase in money or personnel would be the most impactful solution to their limitations, suggesting that education and trust with farmers was most critical.

The final prompt of the survey read, "As you were answering these questions, were there any comments or thoughts that you would like to share?" In total we received 41 additional comments, which revealed several important ideas for expanding soil health in Nebraska. Many expressed a general need for increased communication; for example, a staff person at an eastern Nebraska NRD said, "This is an important area of emphasis that needs much more work and communication with farmers and landowners." The benefits of increased communication and education are consistent with research findings that positive predictors of conservation prac- tice adoption included positive attitudes and awareness of conservation practices and programs (Prokopy et al. 2019). Other comments noted the slow pace associated with change; a board member at a central Nebraska NRD said, "Managing for soil health is a new concept. In time it will become a part of most farm operations." An employee at a central Nebraska NRD noted that "NRDs, NRCS, extension, etc. have been at this for years with little headway." While there are a number of organizations and individuals involved in educating and supporting farmers, including local and federal government, agribusiness, University researchers and extension services, as well as other organizations, it could be that the role of the NRDs in education on soil health is dispersed by this diversity of voices. The Nebraska Soil Health Task Force recommendations could be beneficial to centralizing such education and accelerating the slow pace of change thus far.

Comments also reflected the tension that exists within current production practices and shifting to more soil health

\section{Figure 4}

Responses to the question "How much impact do you believe each of the following initiatives would have on soil health in your NRD?"

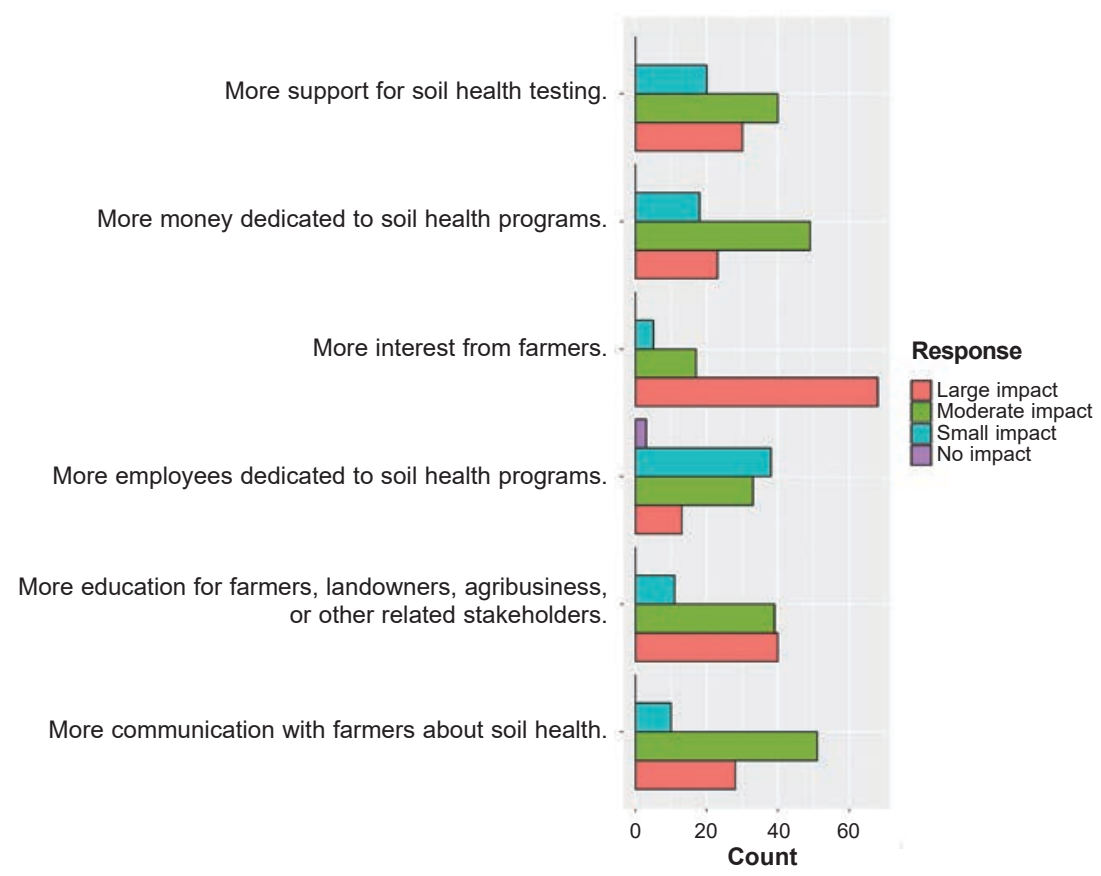

focused management. A board member at an eastern Nebraska NRD said, "The biggest barrier to improving soil health is the economics of corn/soybeans...if big ag isn't buying, it isn't happening." This is a tension that is recognized by many in the conservation community; even those farmers already utilizing soil health-related practices doubt the expanded use of similar diversified systems without greater incentives (Roesch-McNally et al. 2018). Additionally, research in other geographically similar states finds that individual farmers as well as conservation districts have a propensity to encourage practices already on the ground rather than to promote change (Comito et al. 2013; Houser et al. 2020).

\section{SURVEY LIMITATIONS}

We hoped to reach more individuals associated with the NRDs but found that it was challenging to locate contact information. Although we individually contacted all 23 NRDs in regards to our survey, we were not able to aggregate any contact information for 5 NRDs. Some NRDs 
provided individual email addresses, others provided a shared email address, others did not respond, and others chose not to provide us with contact information. Further, we received some comments from participants that our survey was broad, including comments such as "Often these surveys are hard to answer because the questions are generalized" and "I did not answer some of the questions, since I did not know how to answer." However, the goal was to capture general information about perceptions of soil health. Responses demonstrate broadly favorable perceptions of soil health and insightful ideas and approaches to expand soil health related practices.

This does suggest, however, that some questions were interpreted differently by different individuals. For example, we worked to clarify "soil health programs" directly in the survey, but programmatic work varies greatly from organization to organization. This is why our effort included review of publicly available budgets to understand the dollars associated with conservation programs, cost share dollars, or how the budgets accounted for the facilitation of conservation program dollars. We found it difficult to discern how funds are specifically being allocated toward soil health initiatives. This could also be related to the fact that soil health has not primarily been an area of emphasis for NRDs relative to water quality and water quantity, and that it is sometimes difficult to delineate differences between conservation topics.

\section{WORKING FOR NEBRASKANS AND THE LAND}

The overarching goal of our survey was to hear directly from those who are responsible for executing Nebraska's natural resources policies, given that they are likely to be on the "front lines" of carrying out future expanded initiatives related to soil health. Of our respondents, most have very favorable impressions of the benefits of soil health on their work. Regardless of position or length of time with the NRD, we found broad agreement that improving soil health can provide cobenefits to reduce environmental impacts, including addressing both water quality and quantity challenges. It is also clear that there are a number of commonly utilized conservation practices that they perceive to have large potential to impact soil health, including diverse crop rotations, cover crops and no-till. Respondents noted that different NRDs had a range of funding associated with soil health, and programs included cost share, education, research, and demonstrations. The largest opportunity to expand soil health practices identified by NRD respondents was more interest from farmers, with comments reflecting the tensions that exist between current farm production and a shift toward more soil health-related practices. Given the growing interest in soil health across a wide range of stakeholders, we believe increased transparency and communication about ongoing, innovative programs and investments made across NRDs will be beneficial. NRD employees and board members have an important role to play alongside farmers and the community to stimulate soil health, in spite of perceived constraints associated with current conventional production systems and a slow pace of change.

\section{ACKNOWLEDGEMENTS}

We would like to thank the Natural Resources Districts personnel who participated in the survey. We would also like to recognize Steve Thomas, professor, School of Natural Resources, University of Nebraska-Lincoln, Lincoln, Nebraska; Crystal Powers, research and extension communication specialist, Nebraska Water Center, Lincoln, Nebraska; Marie Krausnick, water department manager, Upper Big Blue Natural Resources District, York, Nebraska; John Winkler, general manager, Papio Missouri River Natural Resources District, Omaha, Nebraska; and the Bureau of Sociological Research at the University of Nebraska-Lincoln for their review of the survey and prior drafts of this work. Support for this work came from the Cabela's Apprenticeship program at the University of Nebraska. The University of NebraskaLincoln's Institutional Review Board reviewed and approved this survey as exempted under Category $2 b$ (Project ID 19476).

\section{REFERENCES}

Central Platte NRD (Natural Resources District). 2020. Groundwater Quality. Grand Island, NE: Central Platte Natural Resources District. http:// cpnrd.org/Groundwater-Quality/.
Comito, J., J. Wolseth, and L.W. Morton. 2013. The state's role in water quality: Soil and water conservation district commissioners and the agricultural status quo. Human Organization 72(1):44-54.

CRS. (Congressional Research Service). 2019. Agricultural Conservation: A Guide to Programs. https://crsreports.congress.gov/product/pdf/R/ R40763.

FAO (Food and Agriculture Organization). 2011.The State of the World's Land and Water Resources for Food and Agriculture: Managing Systems at Risk. Rome: Food and Agriculture Organization of the United Nations. http://www.fao.org/3/ i1688e/i1688e00.pdf.

Harrigan, K., and A. Charney. 2019. Impact of 2018 Farm Bill Provisions on Soil Health. Washington, DC, and Morrisville, NC: National Sustainable Agriculture Coalition and Soil Health Institute. http://sustainableagriculture.net/wp-content/ uploads/2019/09/FINAL-DIGITAL-Impact-of2018-Farm-Bill-Provisions-on-Soil-Health.pdf.

Houser, M., R. Gunderson, D. Stuart, and R.C. Denny. 2020. How farmers "repair" the industrial agricultural system. Agriculture and Human Values 1-15. https://doi.org/10.1007/ s10460-020-10030-y.

Little Blue NRD (Natural Resources District). 2019. FY 2019 Property Tax Levy Report. Davenport, NE: Little Blue Natural Resources District. http://littlebluenrd.org/wp-content/ uploads/2018/09/FY_2019-Levy-Summary.pdf. NAPA (Nebraska Auditor of Public Accounts). 2019. Reports. Lincoln, NE: Nebraska Auditor of Public Accounts. https://www.nebraska.gov/ auditor/reports/index.cgi.

NDA (Nebraska Department of Agriculture). 2019. Healthy Soils Task Force. Lincoln, NE: Nebraska Department of Agriculture. https://nda.nebraska. gov/healthysoils/index.html.

NRD (Nebraska's Natural Resources Districts). 2020. About. Lincoln, NE: Nebraska Association of Resources Districts. https://www.nrdnet.org/ nrds/about-nrds.

Prokopy, L.S., K. Floress, J.G. Arbuckle, S.P. Church, F.R. Eanes, Y. Gao, B.M. Gramig, P. Ranjan, and A.S. Singh. 2019. Adoption of agricultural conservation practices in the United States: Evidence from 35 years of quantitative literature. Journal of Soil and Water Conservation 74(5):520-534, doi:10.2489/jswc.74.5.520.

Roesch-McNally, G.E., A.D. Basche, J.G. Arbuckle, J.C.Tyndall, F.E. Miguez, T. Bowman, and R. Clay. 2018. The trouble with cover crops: Farmers' experiences with overcoming barriers to adop- 
tion. Renewable Agriculture and Food Systems 33(4):322-333.

Sixt, G.N., L. Klerkx, J.D. Aiken, and T.S. Griffin. 2019. Nebraska's Natural Resource District system: Collaborative approaches to adaptive groundwater quality governance. Water Alternatives 12(2):676-698. http://www.water-alternatives. org/index.php/alldoc/articles/volume-12/ v12issue2/498-a12-2-5/file.

Upper Big Blue NRD (Natural Resources District). 2020a. Project Grow. York, NE: Upper Big Blue Natural Resources District. https://www.upperbigblue.org/programs/project-grow.

Upper Big Blue NRD. 2020b. NRCS Announces \$4.4 Million Award for On-Farm Conservation. York, NE: Upper Big Blue Natural Resources District. https://www.upperbigblue.org/nrcsannounces-44-million-award-farm-conservation.

Upper Republican NRD (Natural Resources District). 2020. Mission. Imperial, NE: Upper Republican Natural Resources District. https:// www.urnrd.org/about/mission.

US Census Bureau. 2020. Nebraska. https://data. census.gov $/$ cedsci $/$ profile?q $=$ Nebraska\&g $=0400$ 000US31\&tid=ACSDP1Y2018.DP05.

USDA ERS (USDA Economic Research Service). 2019. Agricultural Resources and Environmental Indicators. https://www.ers.usda.gov/publications/ pub-details/?pubid=93025.
USDA ERS. 2020. Cash receipts by commodity, state ranking, 2018. https://data.ers.usda.gov/reports. aspx?ID=17844.

USDA NASS (USDA National Agricultural Statistics Service). 2020a. Published crop-specific data layer. Washington, DC: National Agricultural Statistics Service. https://nassgeodata.gmu.edu/ CropScape/.

USDA NASS. 2020b. Census Data Query Tools. Washington, DC: National Agricultural Statistics Service. https://www.nass.usda.gov/ Quick_Stats/CDQT/chapter/1/table/1.

USDA NRCS (USDA Natural Resources Conservation Service). 2020. Field Office Technical Guide. Washington, DC: USDA Natural Resources Conservation Service. https://efotg.sc.egov.usda.gov/\#/.

Webb, N.P., N.A. Marshall, L.C. Stringer, M.S. Reed, A. Chappell, and J.E. Herrick. 2017. Land degradation and climate change: Building climate resilience in agriculture. Frontiers in Ecology and Environment 15(8):450-459.

Zimnicki, T., T. Boring, G. Evenson, M. Kalcic, D.L. Karlen, R.S. Wilson, Y. Zhang, and J. Blesh. 2020. On quantifying water quality benefits of healthy soils. BioScience 70(4):343-352. 